\title{
Sediment yield and soil erosion assessment by using an empirical model of MPSIAC for Afjeh \& Lavarak sub-watersheds, Iran
}

\author{
Zahra Najm $^{1}$, Nastaran Keyhani ${ }^{1}$, Khalil Rezaei ${ }^{2, *}$, Ali Naeimi Nezamabad ${ }^{3}$, \\ Seyed Hamid Vaziri ${ }^{4}$
}

${ }^{1}$ MS.c, Dept. Geology, Islamic Azad University, North Tehran Branch, Tehran, Iran

${ }^{2}$ Assistant Professor, Kharazmi University, Tehran, Iran

${ }^{3}$ Assistant Professor, Islamic Azad University, Saveh Branch, Saveh, Iran

${ }^{4}$ Professor, Dept. Geology, Islamic Azad University, North Tehran Branch, Tehran, Iran

\section{Email address:}

z_geostar@hotmail.com (Z. Najm),n.kihany@gmail.com (N. Keyhani), khalil.rezaei@yahoo.com (Kh. Rezaei), alin58@gmail.com (A.Naeimi Nezamabad),hamid_vaziri@iau-tnb.ac.ir (S. H. Vaziri)

\section{To cite this article:}

Zahra Najm, Nastaran Keyhani, Khalil Rezaei, Ali Naeimi Nezamabad, Seyed Hamid Vaziri. Sediment Yield and Soil Erosion Assessment by Using an Empirical Model of MPSIAC for Afjeh \& Lavarak Sub-Watersheds, Iran, Earth Science. Vol. 2, No. 1, 2013, pp. 14-22. doi: 10.11648/j.earth.20130201.13

\begin{abstract}
Watershed degradation due to soil erosion and sedimentation is one of the major environmental problems in Iran. With respect to the relatively suitable compatibility of MPSIAC model to the arid and semiarid conditions of Iran and lack of hydrometric station in region, we employed the "modified PSIAC model" to estimating of sediment yield and providing sediment yield map in these sub-watersheds. The MPSIAC method incorporates nine environmental factors that contribute to sediment yield of the watershed, this factors are: surface geology, soil, climate, runoff, topography, ground cover, land use, channel and upland erosion. Open-source Geographic Information System (GIS) was used to facilitate the spatial interpolation of the nine model factors and interpretation of predicted sediment yield for the entire watersheds. At first, to enter the available raw data into the GIS framework we digitized the nine factors of maps. In the second stage, digitized maps were encoded with respect to the values of each factor and then these factors of maps were summed together, and finally sedimentation score map was provided. We applied (QS) equation on the sedimentation score map and finally related map was obtained. Various formations basically contain Shaly, Sandstone, Conglomerate and tuff lithology, covered this region more than igneous rocks. The results show that the most values of erosion are in Shaly, Marly, weathered Tuff and alluvial diposites parts of sub-watersheds correlated with sensitive formations such as Karaj and Quaternary sediments. Based on sediment yield map of MPSIAC model, more than $75 \%$ of the total sub-watersheds area was classified at class IV of erosion category with high sedimentation. Sub-basin's erosion were calculated as 769.3 and $583.21 \mathrm{~m} 2 / \mathrm{km} 3$ per year for each Afjeh and Lavarak sub-basins by MPSIAC model, respectively. Linear regression analysis between MPSIAC model results and two of most influencing factors on erosion, the geology and soil erodibility indicated that there was a significant correlation. The results of this paper suggested that the model is suitable for predicting yearly average sediment yield of the Iranian watersheds with similar conditions.
\end{abstract}

Keywords: MPSIAC, GIS, Erosion, Sediment Yield, Afjeh \& Lavarak Sub-Watersheds

\section{Introduction}

Nowadays the degradation of renewable natural resources is one of the most important problems of mankind. Soil is one of the most important natural resources and the erosion of that is an issue that should never be ignored because of its importance in affecting sustainability of regional development $[1,2]$. Soil erosion can effect dynamically balanced watershed system indirectly by increasing water runoff and degrade water quality and cause misdistribution of water in the watershed [3]. Thus, soil erosion is one of the important components of watershed management which also involves planning and managing terrestrial and aquatic ecosystems, surface and groundwater, and land use planning $[3,4]$.

Soil erosion remains a threat to our global soil resource 
[5]. In Iran, it is estimated that the average annual erosion rate of watershed is more than 20 times as much acceptable average level in the world [6]. Soil loss in Iran for the period of 1950 to 1990 has increased tremendously from 500 million to 2200 million tons per year, an increment of more than four folds in four decades [7]. Overgrazing, dry farming and deforestation are the major causes of watershed degradation in Iran [6]. It is estimated that 26.4 million hectares of land in Iran are under the influence of water erosion, and also 35.4 million hectares are under the influence of wind erosion [7]. In Iran, the climate variation and topographic conditions have important role on the increasing of erosion [8]. The problem of erosion is further exacerbated by loss of organic matter in the topsoil that hold the soil particles together due to improper land use activity [9]. Prolong overgrazing and drought will expand the patches of bare soil and worsen the erosion problem [10].

Modeling soil erosion is the process of mathematically describing soil particle detachment, transport and deposition on land surfaces [ 111$]$. Empirical mathematical methods are an inseparable part of any erosion research to estimate the amount of sedimentation $[12,13]$. In watershed management studies, having knowledge on the erodibility of the soil, the state and intensity of erosion, and the expected effect of conservation measures control are of paramount importance in the understanding of erosion. These are especially critical in areas without any gauging station [ 14 ] . Empirical methods are commonly used as a means of expressing existing (actual), expected (forecasted or predicted) and possible (potential) erosion [15]. Lack of data and data precision are the main issues in the application of empirical method [12]. In such cases, the use of equation is limited, and they may not even be useful for making approximate calculations.

In this study, the "Modified PSIAC (MPSIAC) method" which is specially design for arid and semi-arid area in the United States was assessed for its applicability to the Iranian watershed environment $[16,17,18,19,20]$. The MPSIAC was created in 1982 based on PSIAC which was introduced in 1968 for planning purposes by Pacific Southwest Inter Agency Committee in the United States for watershed basins of larger than 10 square mile [21]. This MPSIAC model is more quantitative than the earlier version and the scoring is more reliable [22].

Both models used nine factors to describe the surface and this are: geology, soil, climate, runoff, topography, ground cover, land use, upland erosion and channel erosion. The difference between these methods is that nine equations were used in MPSIAC, whereas in PSIAC method, sediment yield is assumed to be directly proportional to the total numerical values assigned to the nine factors [23].

Resource map preparation for watershed management such as soil erosion map can be assisted by spatial information processing using Geographic Information System (GIS) [2 4,2 5 ]. Geographic Information System can also provide linkages between maps and other information related to geographic location for environmental modeling purposes especially in the watershed management [26,27]. With due attention to the suitable compatibility of MPSIAC model to arid and semiarid conditions of Iran in the erosion and sediment studies of these sub-watersheds was applied. In this study we used newest GIS softwares to obtain a good and accurate result at the least time.

\subsection{The Study Area}

The study areas are Afjeh \& Lavarak sub-watersheds with an area of 4651.95 and 10557.2 hectares. They are located between the latitude of $35^{\circ} 54^{\prime} 23^{\prime \prime}$ to $35^{\circ} 46^{\prime} 55^{\prime \prime}$ North and longitude of $51^{\circ} 50^{\prime} 24^{\prime \prime}$ to $51^{\circ} 38^{\prime} 38^{\prime \prime}$ East in northwest of capital of Iran, Tehran (Figure 1). This region is high mountainous (more than 70\%) and the climate is generally semi-arid with average precipitation of 688.5 \& $713.57 \mathrm{~mm}$ per year for each of the Afjeh and Lavarak sub-basins. In Afjeh, the maximum, minimum and average temperatures are $15.33^{\circ} \mathrm{C}, 4.07^{\circ} \mathrm{C}$ and $9.7^{\circ} \mathrm{C}$, and in Lavarak are $14.75^{\circ} \mathrm{C}, 3.69^{\circ} \mathrm{C}$ and $9.22^{\circ} \mathrm{C}$, respectively.

Sub-watersheds physiographical Specifications are shown in Table 1 and 2. The majority of the slope class in both sub-watersheds are in class 4 (slope angle range of 30 to $65 \%$ ) and class 5 (slope angle range more than 65\%) with $85 \%$ and $42 \%$ of the Afjeh study area and $88 \%$ and $35 \%$ of the Lavarak sub-basin, respectively (Figure 2). The majority of the steep area is around the north and north east of the study area.

Table 1. physiographical Specifications of Afjeh sub-watershed.

\begin{tabular}{lllll}
\hline Area (hectare) & Compactness Coefficient $(* \mathbf{1})$ & Form Factor (*2) & Max Height (m) & Mi nHeight (m) \\
\hline 4651.95 & 1.81 & 0.31 & 3651 & \\
Drainage Density $(* 4)$ & Average of Slope (\%) & Length of main Stream (km) & Time of Concentration (hr) $(* 3)$ \\
8.45 & 30.1 & 14.2 & 1.08 \\
\hline
\end{tabular}


Table 2. physiographical Specifications of Lavarak sub-watershed.

\begin{tabular}{llccc}
\hline Area (hectare) & Compactness Coefficient (*1) & Form Factor (*2) & Max Height (m) & Min Height (m) \\
\hline 10557.2 & 1.46 & 0.52 & 3313 \\
Drainage Density $(* 4)$ & & Average of Slope (\%) & \multicolumn{2}{c}{ Length of main Stream (km) Time of Concentration (hr) $(* 3)$} \\
8.61 & 16.7 & 14.25 & 1.16 \\
\hline
\end{tabular}

Note (*(number); $(* 1)$ Gravelius Equation $\left[K c=28 P / A^{\wedge} 0.5\right)$ A: area $\left(\mathrm{km}^{2}\right), P$ : perimeter $\left.(\mathrm{km})\right](* 2)$ Form Factor in Horton Equation $\left(F=A / L^{\wedge} 2\right)$ A: area $\left(\mathrm{km}^{2}\right), L$ : Length $(\mathrm{km})(* 3)$ Kiripich Equation $\left[T c(h r)=0.00 o 3 L^{\wedge} 0.77 * S^{\wedge}-0.385\right)$ L: Length of stream(main), S: Average of watershed slope (m/m)] (*4) Drainage Density Equation [Dd=L/A: L: Length streams $(\mathrm{km})$, A: area $\left.\left(\mathrm{km}^{2}\right)\right]$

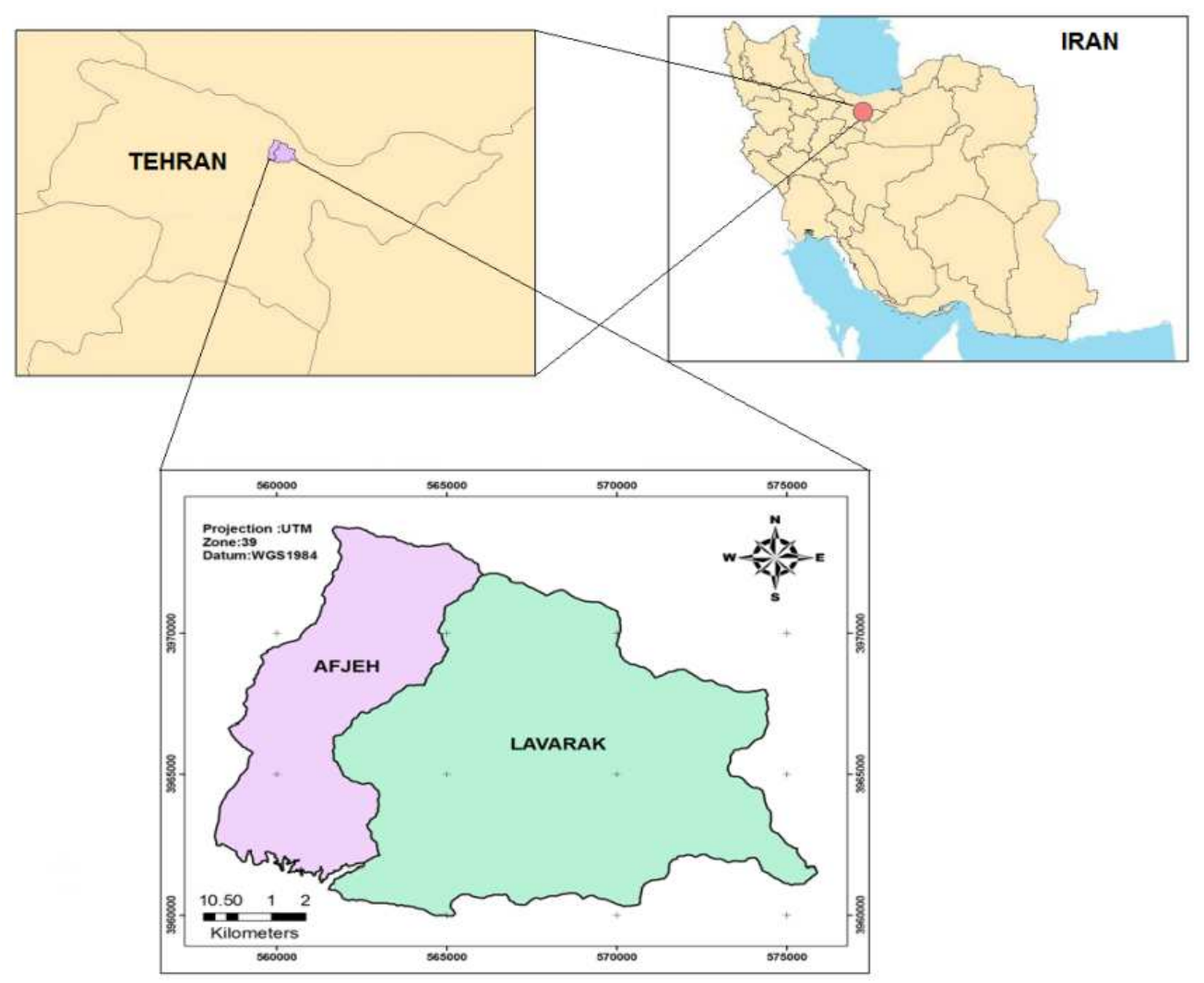

Figure 1. Geographical position of the study area.

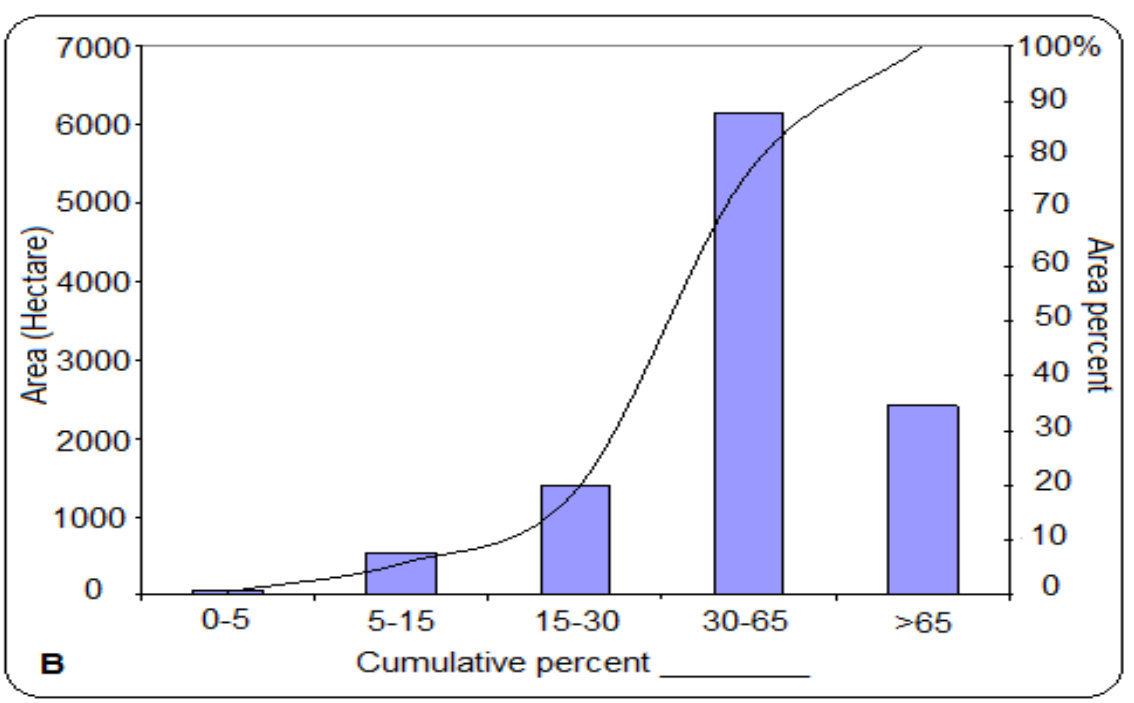




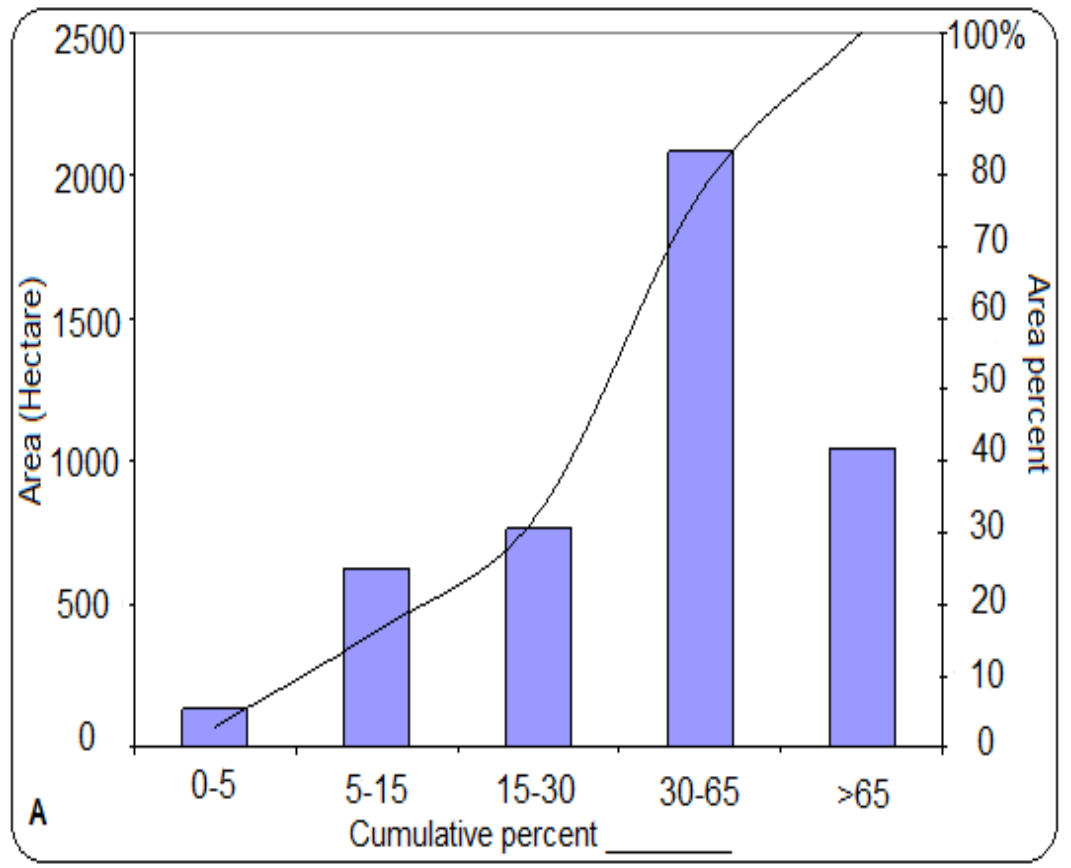

Figure 2. slope angle distribution of the sub-watersheds, A: Afjeh, B: Lavarak.

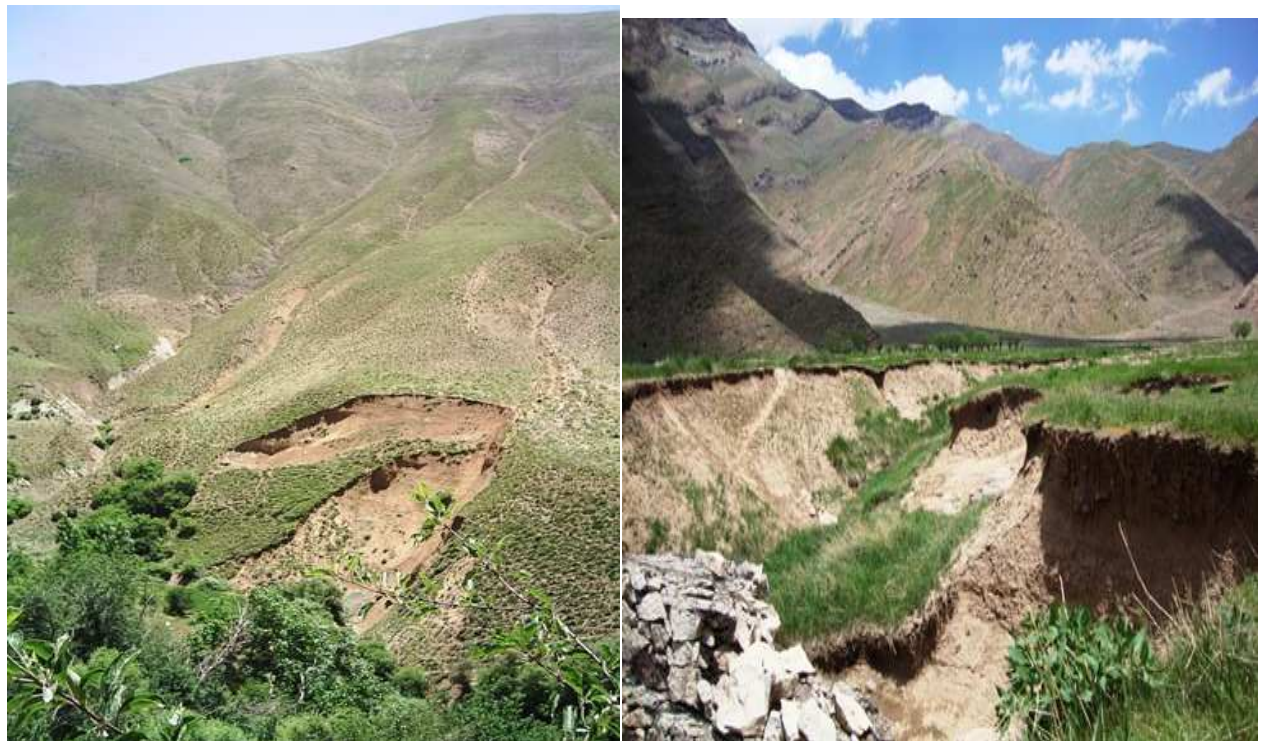

Figure 3. types of erosion in the sub-basins, A:showes rill (RI), stream (ST) and gully (GU) erosion. B: showes gully and bank (BA) erosion.

\section{Materials and Methods}

By reason of the great number of data, activity and changeability of these data in the natural resources, Geographic Information System (GIS), as a useful tool, is carried to solving many problems. MPSIAC model incorporated nine factors from nine equations are: surface geology, soil, climate, runoff, topography, ground cover, land use, erosion condition and channel erosion (Table 3). According to the table, the erosion factors maps were encoded and with overlaying these maps in GIS framework, the sediment yield map in accordance with sediment yield (Qs) equation was obtained. For ease of interpretation, each of the factors is discussed below.

\subsection{Surface Geology}

To calculate this factor, in the first step, geology map (Figure 4) was digitized and then based on the stones sensivity to erosion, this map was encoded and a new data field in the geology map database (based on X1 factor) was created. The score of each unit of surface geology was determined from the scale between 1 for the most resistant face, to 10 for the most sensitive face to erosion. These scaling factors are based on the local condition of Iran [28]. The averages of this factor for each of sub-basins are shown in table 4 . 
Table 3. effective factors on the erosion and calculation method in the MPSIAC model.

\begin{tabular}{|c|c|c|c|}
\hline Description & Equation & Effective factors & No \\
\hline$X_{1}=$ Stones sensivity to erosion $(0-10)$ & $\mathrm{Y}_{1}=\mathrm{X}_{1}$ & Surface geology & 1 \\
\hline $\mathrm{K}=$ soil erodibility & $\mathrm{X}_{2}=16.67 \mathrm{~K}$ & Soil & 2 \\
\hline$P_{2}=6$-hour rainfall with 2-year return period & $\mathrm{X}_{3}=0.2 \mathrm{P}_{2}$ & Climate & 3 \\
\hline $\begin{array}{l}\mathrm{R}=\text { runoff height } \\
\mathrm{Q}_{\mathrm{p}}=1 \text {-year specific pick discharge }\end{array}$ & $\mathrm{X}_{4}=0.006 \mathrm{R}+10 \mathrm{Q}_{\mathrm{P}}$ & Runoff & 4 \\
\hline $\mathrm{S}=$ slope $(\%)$ & $\mathrm{X}_{5}=0.33 \mathrm{~S}$ & Topography & 5 \\
\hline $\mathrm{P}_{\mathrm{b}}=$ bare ground percent & $\mathrm{X}_{6}=0.2 \mathrm{P}_{\mathrm{b}}$ & Land cover & 6 \\
\hline$P_{c}=$ crop canopy percent & $\mathrm{X}_{7}=20-0.2 \mathrm{P}_{\mathrm{c}}$ & Land use & 7 \\
\hline $\mathrm{SSF}=$ the score of soil surface erosion in the BLM method & $\mathrm{X}_{8}=0.25 \mathrm{SSF}$ & Surface erosion & 8 \\
\hline $\mathrm{SSFg}$-the score of gully erosion in the BLM method & $\mathrm{X}_{9}=1.67 \mathrm{SSFg}$ & Gully erosion & 9 \\
\hline \multicolumn{4}{|c|}{$\begin{array}{l}\mathrm{R}=\text { sediment yield score } \mathrm{R}=\mathrm{X}_{1}+16.67 \mathrm{~K}+0.2 \mathrm{P}_{2}+0.006 \mathrm{R}+10 \mathrm{Q}_{\mathrm{p}}+0.33 \mathrm{~S}+0.2 \mathrm{P}_{\mathrm{b}}+20-0.2 \mathrm{P}_{\mathrm{c}}+0.25 \mathrm{SSF}+1.67 \mathrm{SSFg} \\
\mathrm{Q}_{\mathrm{S}}=\text { sediment yield (ton } / \text { hectare } / \mathrm{y} \text { ) } \mathrm{Q}_{\mathrm{s}}=\mathrm{Q}_{\mathrm{S}}=0.253 \mathrm{e}^{0.036 \mathrm{R}}\end{array}$} \\
\hline
\end{tabular}

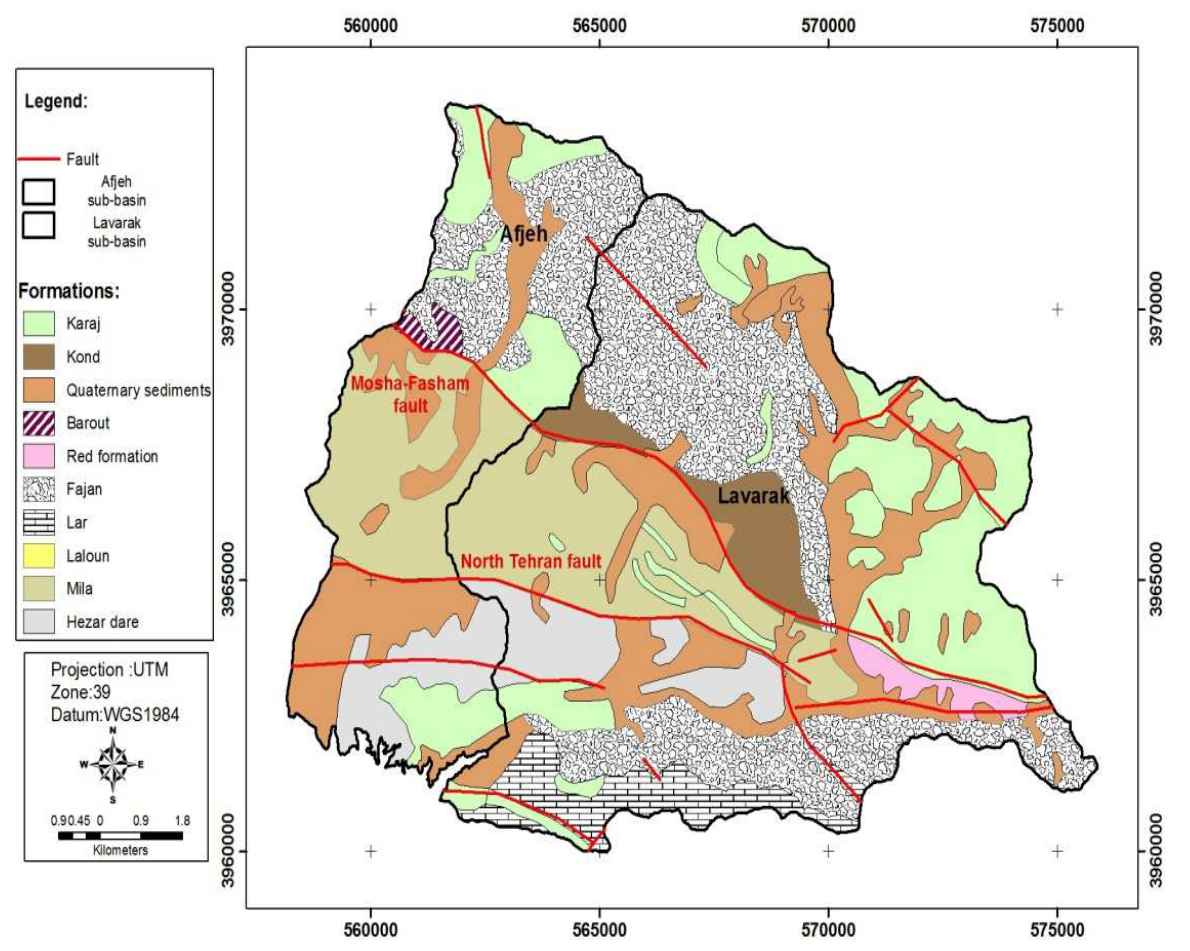

Figure 4. Geology map of Afjeh and Lavarak sub-watersheds.

\subsection{Soil}

With due attention to the soil studies and soil experiments, the effective factors on the $\mathrm{K}$ ( $\mathrm{k}$ is erodibility factor in the USLE method), namely, silt + very fine sand percent, sand percent, organic matter percent, soil structure and permeability were determined and then by using Wischmeir nomograph, $\mathrm{K}$ value and at last $\mathrm{X}_{2}$ value was estimated (Table 4).

\subsection{Climate}

In this model, rainfall is considered as the major contributor to soil erosion and sediment movement. Rainfall was estimated based on 6-hours precipitation amount with 2-year return period. In this study, climate factor was based on 10 years (1999-2008) of rainfall record. From the record, the rainfall intensity duration and frequency curve were derived. The climate factor was estimated and shown in table 4 .

\subsection{Runoff}

Runoff factor was obtained based on analysis of discharge 
data. In the study areas, runoff largely depends on atmospheric conditions and the surface lithology of the formation permeability. According to the runoff equation (table 3), by calculating the average of runoff height (R) and specific pick discharge $\left(\mathrm{Q}_{\mathrm{P}}\right)$, the average of $\mathrm{X}_{4}$ factor in these sub-basins were obtained (Table 4).

\subsection{Topography}

Topography factor was determined based on average percentage of slope steepness. To providing this layer at first by using DEM layer (Figure 5), slope map was obtained and then this map was multiplied by 0.33 , and at last the topographic factor map was obtained (Table 4).

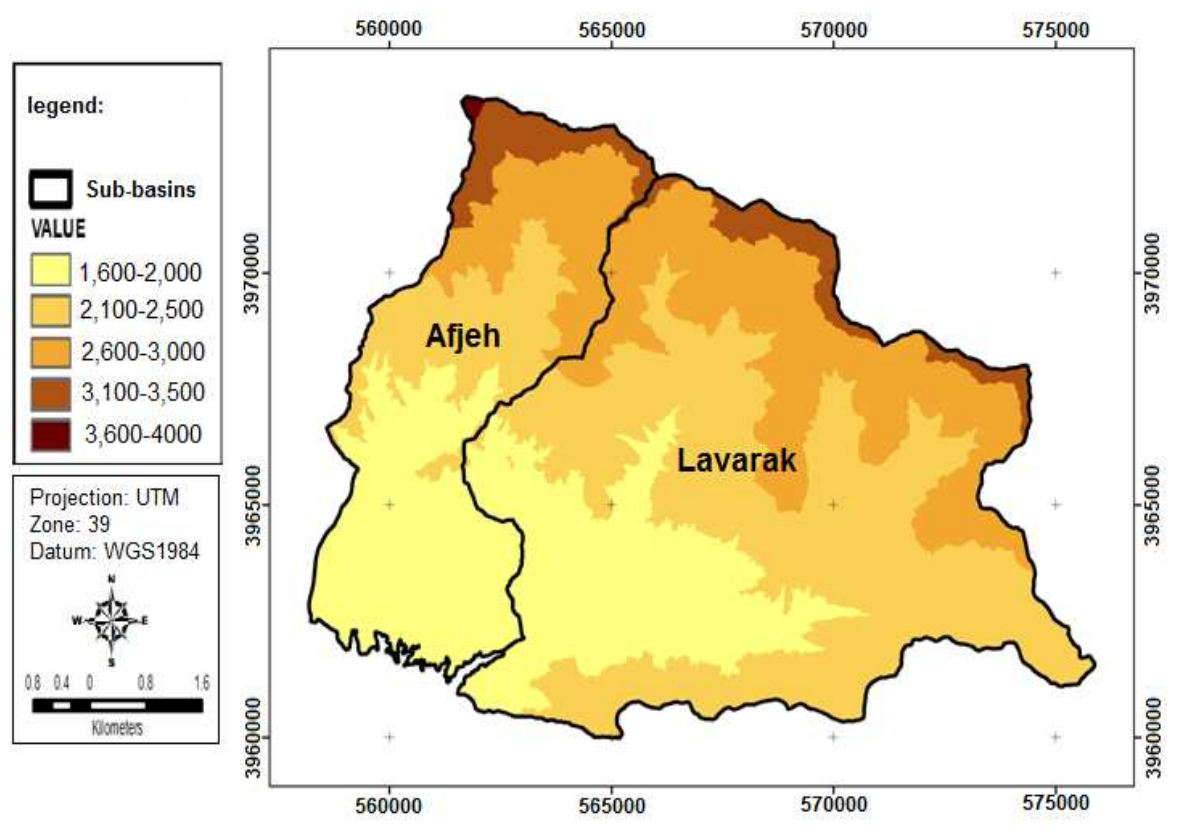

Figure 5. DEM (Digital Elevation Map) for study area.

\subsection{Ground Cover}

The main characteristics considered as ground cover are vegetation, litter and rocks. To providing this factor, at first we digitized plant cover map and then in this map based on the bare grounds percent, a new data field was created.

\subsection{Land Use}

Land use factor was estimated based on canopy cover. With due attention to the crop canopy percent in each cover type and by using Landsat ETM imagery, topographic maps and field visits, plant cover map based on $\mathrm{X}_{7}$ value was encoded.

\subsection{Erosion Condition}

Upland erosion factor was obtained based on Bureau of Land Management (BLM) method [29]. This method is used from 7 factor: surface erosion, land cover, rill erosion, surface litter, demolition traces on the ground surface, surface flows traces and gully erosion. By field surveying, IRS and Landsat ETM imagery, the score of these factors was determined and then with digitizing geomorphology map, this map was encoded based on $\mathrm{X}_{8}$ factor value and a new data field (based on $\mathrm{X}_{8}$ factor) was created in this map. The average of this factor in Afjeh and Lavarak sub-basins, are shown in table 4.

\subsection{Channel Erosion}

Channel erosion factor was obtained based on gully erosion factor from the BLM method and by the relationship between yearly rainfall $(\mathrm{mm})$ and gully erosion improvement [30]. Based on this factor, geomorphology map was encoded and a new

data field in this map was created. The average of this factor in sub-watersheds were obtained (Table 4).

Table 4. The average score of MPSIAC factors in Afjeh and Lavarak sub-watersheds.

\begin{tabular}{lllllllllll} 
Watershed name & F1 & F2 & F3 & F4 & F5 & F6 & F7 & F8 & F9 \\
\hline Afjeh & 4.12 & 5.37 & 2.65 & 15.07 & 16.07 & 6.31 & 13.23 & 16.5 & 16.7 \\
Lavarak & 5.16 & 3.27 & 8.13 & 15.03 & 14.05 & 4.75 & 14.62 & 14.75 & 8.35 \\
\hline
\end{tabular}

\subsection{Providing of Sediment Yield Score Map and Sedi- ment Yield Map}

Utilising GIS, spatial data related to surface geology, soil types, climate, runoff, topography, ground cover, land use, surface erosion and channel erosion were incorporated into MPSIC model to facilitate the prediction and assessment of sediment yield of the sub-watersheds. Summation of scores in this nine environmental factors is called sediment yield score (R) (Figure 5). To calculate $\mathrm{R}$ in the ArcGIS framework, at first all nine factors rasterized by using raster calculator menu and then combined with each other. In other words, the coordinates of the cells are combined and inte- 
grated; for this case, the data should be in rasteric structure to allow for their integration in ArcGIS framework.

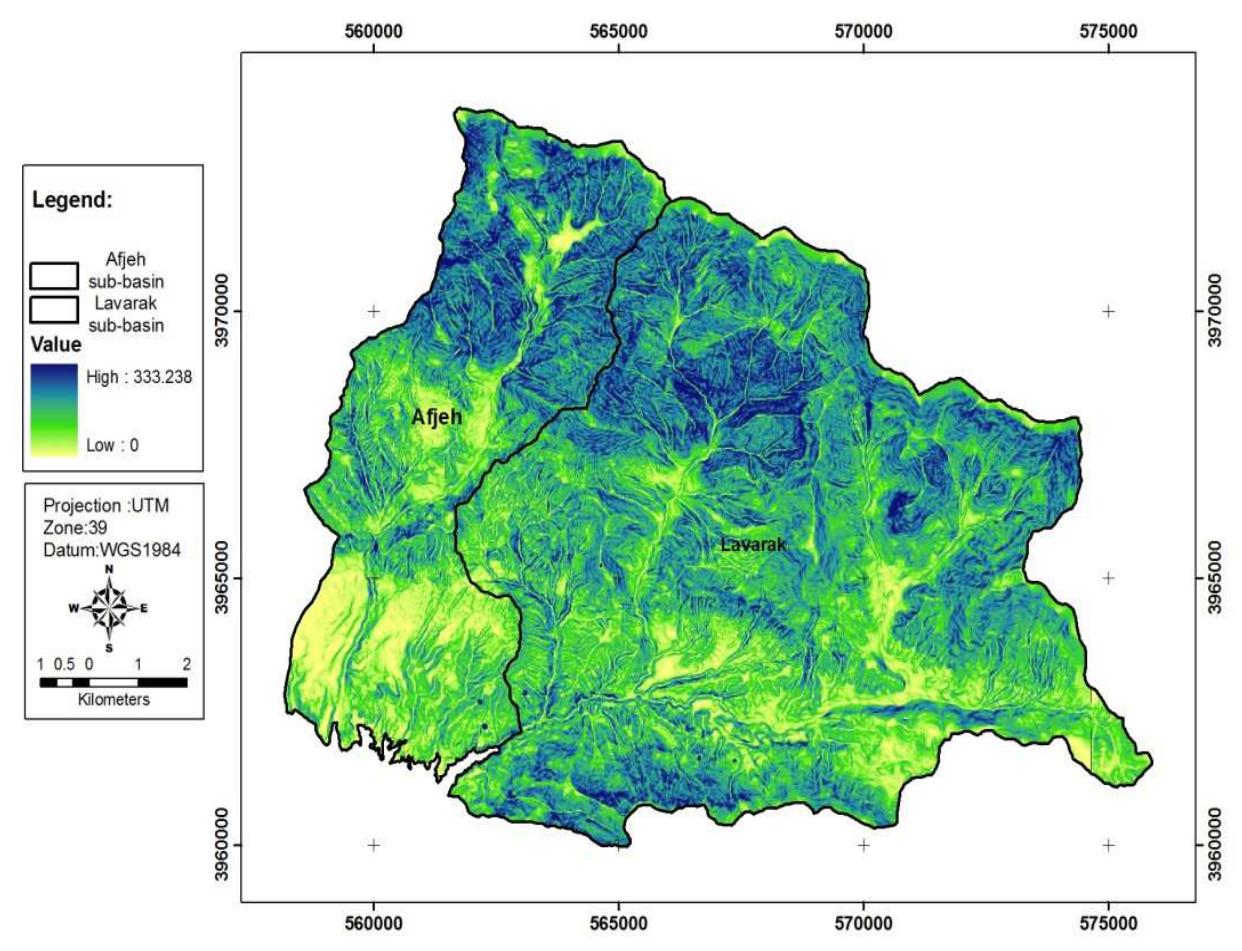

Figure 5. sediment yield score (R) map (sub-watersheds of Afjeh and Lavarak).

Sediment score (R) was employed to estimate sediment yield (QS) according to Johnson \& Gebhardt formula [31]:

$\mathrm{QS}=0.253 \mathrm{e} 0.036 \mathrm{R}$

$\mathrm{QS}=$ sediment yield (ton/hectare/y)

$\mathrm{R}=$ sediment yield score

\section{Results}

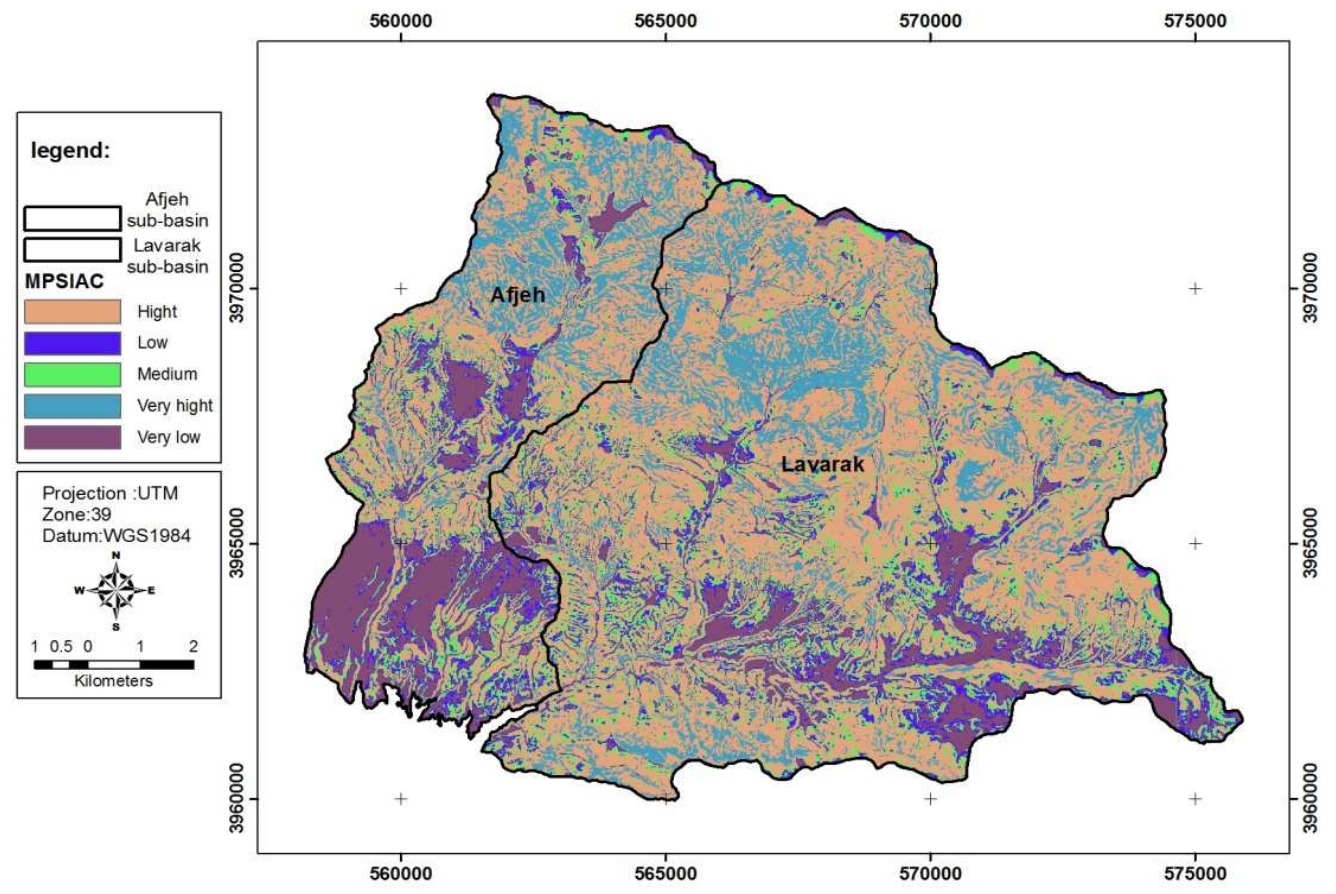

Figure 6. sediment yield (QS) map (sub-watersheds of Afjeh and Lavarak).

Accordingly, the sediment yield score map of Afjeh and Lavarak sub-basins was prepared (Figure 6). Then based on the table 5, the sediment yield map were classified and the result is shown in table 6 . 
Table 5. sediment yield classes in the MPSIAC model.

\begin{tabular}{llll}
\hline $\begin{array}{l}\text { Sediment yield } \\
\text { scores }\end{array}$ & $\begin{array}{l}\text { The amount of } \\
\text { sediment } \\
\text { yield }\left(\mathbf{m}^{3} / \mathbf{k m}^{2} / \mathbf{y}\right)\end{array}$ & $\begin{array}{l}\text { Sediment yield } \\
\text { intensity }\end{array}$ & $\begin{array}{l}\text { Sediment yield } \\
\text { class }\end{array}$ \\
\hline$>100$ & $>1429$ & Very high & V \\
$75-100$ & $476-1429$ & Hight & IV \\
$50-75$ & $238-476$ & Medium & III \\
$25-50$ & $95-238$ & Low & II \\
$<25$ & $<95$ & Very low & I \\
\hline
\end{tabular}

Table 6. sediment yield score and class in Afjeh and Lavarak sub-watersheds.

\begin{tabular}{llll}
\hline $\begin{array}{l}\text { Watershed } \\
\text { name }\end{array}$ & $\begin{array}{l}\text { Sediment yield } \\
\left(\mathbf{m}^{\mathbf{3}} / \mathbf{k m}^{2} / \mathbf{y}\right)\end{array}$ & $\begin{array}{l}\text { Sediment yield } \\
\text { intensity }\end{array}$ & $\begin{array}{l}\text { Sediment } \\
\text { yield } \\
\text { class }\end{array}$ \\
\hline Afjeh & 769.3 & Hight & IV \\
Lavarak & 583.21 & Hight & IV \\
\hline
\end{tabular}

Finally, to performance evaluate and examination of MPSIAC model, note that the study areas were lack of surveyed deposition stations hydrometrical and sediment measurement stations and on the other hand, data obtaind from this complex, because of too many errors, especially in the spring, could not be a suitable index to compare, we decided to use statistical comparision between MPSIAC model results and tow of most influencing factors on erosion, the geology and soil erodibility. Coefficient of concordance between elements, shows high correlation between erodibility indexes and the modified model (MPSIAC) results (Table 7).

Table 7. linear regression analysis between MPSIAC results and erodibility indexes.

\begin{tabular}{ll}
\hline Index & MPSIAC \\
\hline Geology (formation) erodibility & 0.754123 \\
Soil erodibility & 0.841236 \\
\hline
\end{tabular}

\section{Conclusions}

With due attention to the studies and surveying of these sub-watersheds, types of erosion that have the largest land areas in the region are rill, stream and gully erosions. Also most values of erosion are in Shaly, Marly, weathered Tuff and alluvial diposites parts; which are sensitive and basically covered this rigion. Thus with applying the reformatory programs and considering these sub-watersheds formations, are often sensitive to erosion, we can decrease erosion. According to sediment score that estimated from the established MPSIAC model, more than $75 \%$ of the total sub-watersheds area falls within a class IV of erosion category which is considered to be high. Sediment yield were calculated as 769.3 and $583.21 \mathrm{~m} 2 / \mathrm{km} 3$ per year in Afjeh and Lavarak sub-basins by MPSIAC model, respectively.
The most sensitive factors to the model output are topography, runoff and surface erosion. For instance, increase in height and slope can cuse increase in runoff which in turn leads to increase in the erosion rate in the region. At last, linear regression analysis between MPSIAC results and erodibility indexes (geology and soil erodibility) shows high conformity. Because of this reason, and also by the statistical evaluation of data and information, we reached the conclusion that MPSIAC model results, shows high conformity with reality. With due attention to the obtained results and studied sub-basins conditions, obtained sediment has good accuracy. The nine factors in MPSIAC model almost represent all agents that affected soil erosion and sedimentation either directly or indirectly.

\section{References}

[1] Jiao, J.Y., Tzanopoulos, J., Xofis, P. and Mitchley, J., 2008. Factors affecting distribution of vegetation types on abandoned cropland in the hilly-gullied Loess Plateau region of China. Pedosphere 18 (1), 24-33.

[2] Wilson, G.V., McGregor, K.C. and Boykin, D., 2008. Residue impacts on runoff and soil erosion for different corn plant populations. Soil \& Tillage Research 99, 300-307.

[3] Black, P.E., 1982. Watershed Hydrology. New York: Prentice Hall.

[4] Chess, C. and Gibson, G., 2001. Watersheds are not equal: Exploring the feasibility of watershed management, Journal of the American Water Resources Association 37(4): 775-782.

[5] Larney, F.J., Janzen, H.H., Olson, B.M. and Olson, A.F., 2009. Erosion-productivity-soil amendment relationships for wheat over 16 years. Soil \& Tillage Research 103 (2009) p73-83.

[6] Jalalian, A., Ghahsareh, A.M. and Karimzadeh, H.R., 1997. Soil erosion estimation for some watershed in Iran. Isfahan: Isfahan University of Technology.

[7] Ahmadi, H., 1995. Applied Geomorphology. Tehran; Tehran University. (In Persian).

[8] Lal, R., 1999. Erosion impact on soil quality in the topics. In: Lal, R (ed) Soil quality and soil erosion, Soil and Water Conservation Society and CRC Press, Boca Raton, 285-305.

[9] Meamarian, H., Tajbakhsh, S.M. and Esmaeilzadeh, H., 2003. The Sediment yield potential estimation of Kashmar urban watershed using MPSIAC model in the GIS framework, Map India Conference 2003, Poster Session.

[10] Nikkami, D., Elektorowicz, M. and Mehuys, G., 2002. Optimizing the management of soil erosion, Water Quality Resource Journal of Canada, 37(3): 577-586.

[11] Blaszczynski, J., 2001. Regional sheet and Rill Soil Erosion Prediction with the RUSLE-GIS Interface, Bureau of Land Management Resource Notes No. 46. http://www.blm.gov/nstc/resourcenotes/respdf/RN46.pdf Access on 22 October 2004.

[12] Wijeskera, S. and Samarakoon, L., 2002. Extraction of pa- 
rameters and modeling soil erosion using GIS in a grid environment. Colombo: Sri Lanka Publishing Company.

[13] Zachar, D., 1982. Soil Erosion. Development in Soil Science 10. Amsterderm, Elsevier.

[14] Bartsch, K.P., Van Miegroet, H., Boettinger, J., and Dobrowolski, J.P., 2002. Using empirical models and GIS to determine erosion risk at Camp Williams, Utah, Journal of Soil and Water Conservation, 57(1): 29-37.

[15] Noman, A.A. and Tahir, T.M., 2002. Rainfall-Runoff Erosion Model for semi-arid catchments using GIS, Journal of $\begin{array}{lll}\text { Science and Technology. } & \text { 7(2): }\end{array}$ http://www.ust.edu/sj/Rainfall.htm. Accessed on 23 July 2004.

[16] Ghadiri, H., 1990. Soil Conservation. Tehran: University of Ahwaz (In Persian).

[17] Haregeweyn, N., Poesen, J., Nyssen, J., Verstraeten, G., Vente, G.D., Govers, G., Deckers, S. and Moeyersons, S., 2005. Specific sediment yield in Tigray-Northern Ethiopia: assessment and semi-quantitative modeling. Geomorphology $69,315-334$.

[18] Mahmoodabadi, M. and Refahi, H.G., 2005. Sediment Yield Assessment Using MPSIAC Model in GIS Framework. Tehran University, Tehran.

[19] Meamarian, H. and Esmaeilzadeh, H., 2003. The Sediment yield potential estimation of Kashmar watershed (Iran) using MPSIAC model in the GIS framework. http://www.gisdevelopment.net/application/2003.

[20] Safamanesh, R., Azmin-Sulaiman, W.N. and Ramli, F.M., 2006. Erosion risk assessment using an empirical model of pacific south west inter-agency committee method for Zargeh watershed, Iran. Spatial Hydrology 1, 105-120.

[21] Tajgarddan, T., Ayoubi, S.H., Shtei, A. and Jouybari, S.H., 2008. Soil erosion and sediment yield assessment using MPSIAC model, remote sensing and geographic information systems (Case study: Ziarrat watershed). Pajouhesh-va-Sazandegi (Iran) 21 (79), 37-45.

[22] Millward, A.A. and Mersey, J.E., 2001. Conservation strategies for effective land management of protected areas using an erosion prediction information system, Journal of Envi- ronmental Management, 91: 329-343.

[23] Pacific Southwest Inter Agency Committee (PSIAC), 1968. Factor affecting sediment yield and measurement for the reduction of erosion and sedimentation yield. Portland: United States Department of Agriculture Soil Conservation Service.

[24] Heshmati, M., Arifin, A., Shamshuddin, J. and Majid, N.M., 2012. Predicting N, P, K and organic carbon depletion in soils using MPSIAC model at the Merek catchment, Iran, Geoderma journal 175-176 (2012) p 64-77.

[25] PSIAC (Pacific Southwest Interagency Committee), Erosion and sediment yield methods. Mimeo. Rep, USDA Soil Conservation Service, Portland, Oregon.

[26] McHugh, M., Walling, D., Wood, G., Zhang, Y., and Williamson, A., 2002. Prediction of sediment delivery to water courses from land. National Soil Resources Institute, Cranfield University.

[27] Green, D.R. and Rix, D., 1995. The Association for Geographic Information Sourcebook for GIS. London: Association for Geographic Information.

[28] Shrestha, M.N., 2002. Assessment of hydrological changes due to landuse modifications, Unpublished Ph.D thesis. Indian Institute of Technology, India.

[29] Feiznia, S., 1995. Natural Resources Journal of Tehran University,No.47:17-21.

[30] Aker, A., 1971. Soil Surface Factors, Determination of erosion condition class. Bureau of Land Management, Department of Interior, USA, form 7310-12.

[31] Najafinejad, A., 2003. Gully erosion measurement in loess hilly area. Unpublished Ph.D. thesis, Gorgan University, Iran. (In Persian).

[32] Johnson, C.W. and Gebhardt, K.A., 1982. Predicting sediment yield from Sagebrush Rangelands, U.S. Dept. of Agriculture, SEA, Agricultural Research Service, Agricultural Reviews and Manuals, AEW-Western Series, no.26. pp. 145-156. 